JURNAL PANGAN DAN GIZI Vol (No): 60-73, April 2020

ISSN (Online) : 2656-0291

Tersedia online di http://jurnal.unimus.ac.id/index.php/JPDG

\title{
SIFAT KIMIA DAN SENSORI SERBUK BERAS HITAM DENGAN VARIASI METODE PEMASAKAN DAN PENAMBAHAN BUBUK KEDELAI
}

\author{
Chemical Properties and Sonsori Black Rice Powder with Variation of Cooking \\ Method and Addition of Soy Powder \\ Diksy Zeta Amorta. Nurhidajah \\ Program Studi S1 Teknologi Pangan \\ Universitas Muhammadiyah Semarang \\ E-mail : diksy.zetaa@gmail.com
}

\begin{abstract}
Black rice is one of the world's rice varieties, in addition to white rice, brown rice, and brown rice. The content of anthocyanin and its antioxidant activity is greater than other types of rice. Therefore, this research done as one effort to exploit black rice. The general purpose of this study was to determine the levels of anthocyanin, antioxidant activity, sensory properties and determine the best treatment. Cooking methods (roasting and oven) and the addition of soy powder (0, 10gr, 20gr, 30gr, 40gr). This study used a Factorial Completely Randomized Design with anthocyanin and DPPH antioxidant activity. The result of statistical test shows hat cooking method and addition of soybean powder have an effect on anthocyanin content, antioxidant activity and sensory properties. The best treatment was roasting and 10 gr from 10 gr weight of black rice with anthocyanin content 4,67 ppm, antioxidant activity $29,80 \%$, sensory value 2,77 (close to likes) and protein value 14,68\%. The value of water content in powdered black rice powder also in accordance with standard water content in powder powder ranges from $3 \%$ to $5 \%$.
\end{abstract}

Keywords: black rice, soybeans, antioxidant activity, anthocyanins.

\section{PENDAHULUAN}

Beras terbagi menjadi tiga jenis

berdasarkan warnanya, yaitu beras putih,

beras merah dan beras hitam. Beras hitam

adalah jenis beras yang memiliki

karakteristik fisik yang unik, yaitu berwarna hitam. Indonesia merupakan produsen beras hitam ketiga terbesar di dunia setelah China dan Sri Lanka. Akan tetapi, pemanfaatan beras hitam di Indonesia masih belum dilakukan secara 
optimal. Beras hitam tidak banyak dikonsumsi karena memiliki tekstur yang lebih keras dibandingkan dengan beras putih. Beras hitam dapat diolah menjadi berbagai macam produk makanan, seperti nasi, bubur, snack, dan produk serbuk. (Mangiri et al., 2016).

Seiring dengan perkembangan ilmu pengetahuan dan perubahan gaya hidup masyarakat yang semakin kritis terhadap konsumsi makanan dan minuman untuk menunjang kesehatan, sehingga masyarakat akan lebih selektif dalam memilih suatu produk pangan. Kesibukan dan aktivitas dari masyarakat di era modern menuntut produsen produk pangan menciptakan sebuah inovasi produk pangan yang dapat disajikan dengan cepat dan praktis namun tetap memperhatikan kelengkapan nilai gizinya. Salah satu produk pangan yang dapat di buat berdasarkan permasalahan tersebut adalah serbuk instan beras hitam. Kemudahan dalam mengkonsumsi serbuk ini adalah praktis yaitu dengan cara menuangkan air hangat atau panas selain itu bentuknya yang serbuk (kadar air rendah) sehingga daya simpannya lama.

Komponen kimia dalam beras hitam sangat bermanfaat untuk kesehatan tubuh, diantaranya kadar antosianin yang dimiliki beras hitam lebih tinggi dibandingkan dengan beras merah, sehingga beras hitam memiliki warna dominan hitam. Antosianin yang banyak terdapat dalam beras hitam, seperti.peonidin, peonidin 3glukosida dan sianidin 3-glukosida bermanfaat memberikan efek inhibitor pada serangan sel kanker (Chen et al., 2006 dalam Sompong et al., 2011). Pengolahan beras hitam diharapkan menjadi salah satu produk pangan yang tidak hanya sebagai inovasi pangan namun dapat memberi kontribusi dalam pemecahan masalah kesehatan yang dialami kebanyakan masyarakat Indonesia, salah satunya adalah dengan membuat pangan fungsional dengan bahan dasar beras hitam diikuti dengan bahan-bahan 
lainya yang tentunya juga menunjang

manfaat produk tersebut.

Variabel yang akan mempengaruhi dalam pembuatan serbuk beras hitam ini diantaranya penambahan bubuk kedelai sebagai sumber protein dan variasi metode pemasakan yang berbeda. Winarsih (2010) mengemukakan bahwa kandungan protein kedelai cukup tinggi sehingga kedelai termasuk ke dalam lima bahan makanan yang mengandung berprotein tinggi. Kacang kedelai mengandung air 9\%, protein $40 \%$, lemak $18 \%$, serat $3.5 \%$, gula $7 \%$ dan sekitar $18 \%$ zat lainnya. Penambahan bubuk kedelai perlu dilakukan untuk menambah nilai protein pada serbuk beras hitam. Tujuan dalam pemberian bubuk kedelai dalam penelitian ini adalah adanya peningkatan nilai protein terhadap serbuk beras hitam pada masingmasing prosentase penambahan yang berbeda. Proses perendaman, pemasakan, dan pengupasan kulit dapat berpengaruh dalam pembuatan serbuk beras hitam, yaitu dapat mengurangi kandungan senyawa gizi dan komponen nutrisi yang ada dalam bahan pangan (Mohamed et al., 2011).

Metode pemasakan yang digunakan dalam penelitian ini adalah oven dan sangrai dan masing-masing mempunyai cara yang sama yaitu pengolahan bahan pangan dengan menggunakan suhu tinggi. Pengolahan pangan dengan menggunakan pemanasan dikenal dengan proses pemasakan yaitu proses pemanasan bahan pangan dengan suhu $100^{\circ} \mathrm{C}$ atau lebih dengan tujuan utama adalah memperoleh rasa yang lebih enak, aroma yang lebih baik, tekstur yang lebih lunak, untuk membunuh mikrobia dan menginaktifkan semua enzim. Pemasakan dapat dilakukan dengan perebusan dan pengukusan, baking (pemanggangan roti), roasting (pengsangraian) dan frying (penggorengan dengan minyak) dengan suhu antara $150^{\circ}$ $300^{\circ}$ C. Penggunaan panas pada masingmasing proses pemasakan memiliki pengaruh yang beda pada nilai gizi bahan pangan (Sumiati, 2008), 
Menurut Syarifa (2009) ada dua hal penting yang dipertimbangkan mengapa pengolahan bahan pangan perlu dilakukan yaitu pertama adalah untuk mendapatkan bahan pangan yang aman untuk dikonsumsi sehingga nilai gizi yang terkandung dapat dimanfaatkan secara maksimal dan yang kedua adalah agar bahan pangan tersebut dapat diterima. Penelitian ini bertujuan untuk mengetahui bagaimana pengaruh proses pemasakan sangrai dan oven terhadap kadar antosianin dan aktivitas antioksidan pada serbuk beras hitam. Proses pemasakan sangrai dan oven dapat mengakibatkan kehilangan sejumlah komponen nutrisi terutama yang bersifat labil seperti asam askorbat, antosianin dan betakaroten (Budhiarto, 2003).

Berdasarkan penelitian Isnaeni (2015) bahwa pembuatan serbuk fungsional beras merah dengan penambahan kedelai hitam dilakukan untuk meningkatkan aktivitas senyawa antosianin sebagai antioksidan dan peningkatan daya terimanya oleh sebagian besar panelis. Penelitian Stevi (2015) menyatakan ada peningkatan aktivitas antioksidan pada perlakukan perendaman dan konsentrasi beras hitam yang berbeda pada serbuk beras hitam. Penelitian Isnaeni (2015) dan Stevi (2015) dapat dijadikan referensi pada pebuatan serbuk beras hitam yang memiliki aktifitas antitoksidan yang lebih tinggi dibandingkan dengan beras putih dan merah.

\section{BAHAN DAN METODE}

\section{Bahan}

Bahan utama pembuatan produk adalah beras hitam varietas lokal Bantul, kedelai varietas grobogan, maltrodekstrin, gula, dan garam. pengujian antosiani: Etanol 95\%, Asam Asetat (merck), $\mathrm{HCl}$ (merck),buffer Potasium Klorida (merck), buffer Potasium Asetat (merck), Larutan $\operatorname{DPPH}(2, \quad$ 2-diphenyl-1-picrylhydrazil), methanol (merck), pengujian serat kasar, kadar abu dan kadar air: $\mathrm{HCl}, \mathrm{H}_{2} \mathrm{SO}_{4}$ (merck), $\mathrm{NaOH}$ (merck), Aceton (merck), Aquades, dan kertas saring whatman. Alat 
yang di gunakan meliputi timbangan, alat

penepung, spektrofotometer dan

seperangkat alat-alat kimia.

\section{Prosedur Penelitian}

\section{Pembuatan Serbuk Beras Hitam}

(Mudjisihono, 2000 Modifikasi)

Proses pembuatan serbuk beras hitam yaitu diawani dengan penepungan beras hitam yaitu pencucian beras hitam, penirisan lalu dimasak dengan perlakuan Oven $\pm 120^{\circ} \mathrm{C}$ selama 1 jam dan si Sangrai $\pm 150^{\circ} \mathrm{C}$ selama 20 menit setelah itu dilakukan penggilingan dengan mesin penepung dan diayak menggunakan ayakan 80 mesh, setelah itu dilakukan pencampuran dengan gula, maltodekstrin, garam dan bubuk kedelai dengan pembuatan bubuk kedelai pertama dilakukan perendaman kedelai selama 7 jam, pengupasan kulit, perebusan api kecil, pengeringan lalu penggilingan dan diayak menggunakan ayakan 80 mesh.

\section{Prosedur Analisis}

Parameter yang diuji meliputi : Aktivitas

Antioksidan; Kadar Antosianin (Winarti et al., 2008) ; Sifat Sensori (Suradi, 2007);

Kadar Air (AOAC, 2005); Kelarutan

(Solubility) Kadar Protein Mikro Kjeldahl

(AOAC, 2005).

\section{Analisis Data}

Analisis data hasil pengukuran aktivitas antioksidan dan kadar antosianin dianalisa deskriptif dan statistik menggunakan uji Anova dengan bantuan komputer dan jika ada pengaruh dimana pvalue $<0,05$ maka diuji lanjut dengan uji Duncan. Data hasil uji sifat sensori dianalisa menggunakan uji Friedman dan jika ada pengaruh $\mathrm{p}$-value $<0,05$ maka uji lanjut dengan uji Wilcoxon.

\section{HASIL DAN PEMBAHASAN}

\section{Kadar Antosianin}

Antosianin menurut Avila et al., (2009) merupakan merupakan pigmen alami yang terdapat dalam buah, sayuran/ serealia yang berwarna merah, biru, ungu hingga kehitaman. Senyawa ini merupakan turunan dari polyhydroxyl atau polymethoxy dari 2-phebyl-benzopyrilium. 
Hasil kadar antosianin dapat dilihat pada Gambar 4.

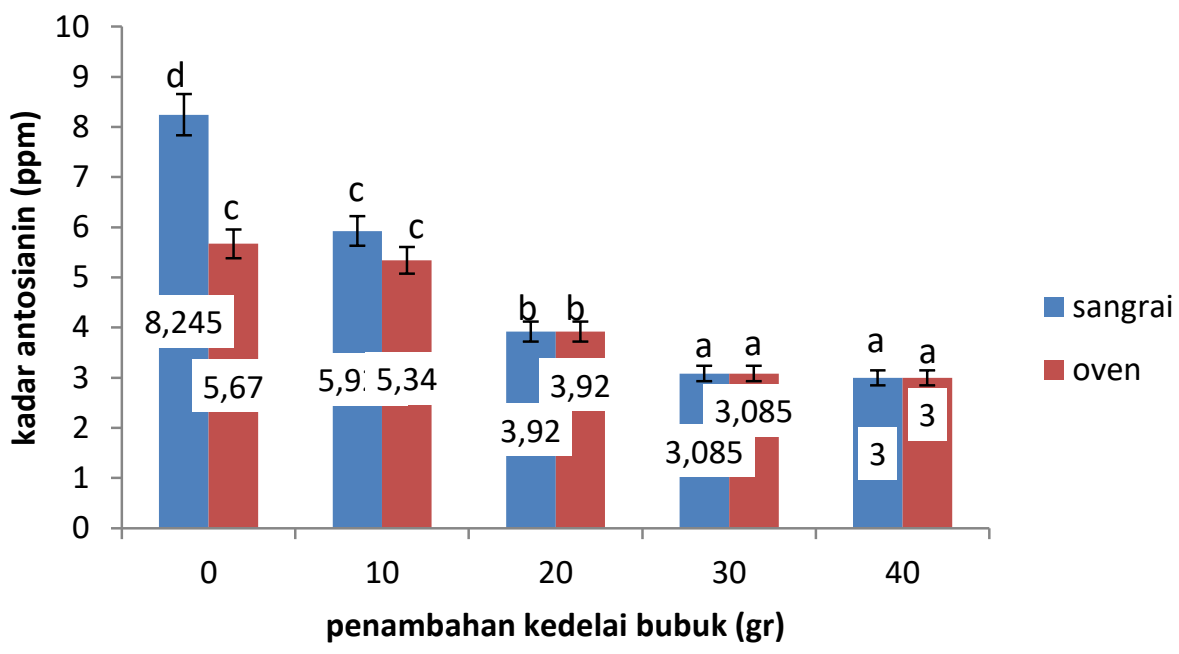

\section{Gambar 4. Nilai Antosianin serbuk beras hitam}

Keterangan: superkrip yang berbeda menunjukan hasil yang berbeda nyata $(p<0,05)$, nilai terendah dimulai dari superskrip a,b, d kemudian d

Uji statistik pada taraf signifikansi $5 \%$

menunjukan bahwa metode pemasakan dan

penambahan bubuk kedelai serta interaksi

antara keduanya ada pengaruh pada serbuk

beras hitam terhadap kadar antosianin, hal

ini ditunjukkan dengan nilai $\mathrm{p}$ metode

pemasakan $0,002 \quad(\mathrm{p}<0,05)$, nilai $\mathrm{p}$

penambahan bubuk kedelai $0,000(\mathrm{p}<0,05)$

nilai $\mathrm{p}$ interaksi metode pemasakan dan

prosentase penambahan bubuk kedelai $\mathrm{p}$

0,001 ( $\mathrm{p}<0,05)$. Hasil uji lanjut Duncan

menunjukan adanya perbedaan nyata.

Kecenderungan kadar antosianin

menurun dengan penambahan bubuk kedelai yang semakin banyak. Hal tersebut sama dengan penelitiaan Syarifah (2016) bahwa penambahan tepung kedelai berpengaruh terhadap kadar antosianin yang cenderung menurun pada snack nori dari kulit buah naga. Antosianin merupakan zat warna yang berperan memberikan warna ungu berpotensi menjadi pewarna alami untuk pangan. Penambahan tepung kedelai dalam konsentrasi tertentu maka pigmen lebih banyak berikatan dengan protein kedelai yang ada dalam produk pangan, maka pigmen dari bahan pangan yang 
dipertahankan semakin berkurang, memiliki berat molekul kecil, tetapi

interaksi asam-asam amino yang ada dalam

produk pangan akan sedikit mengalami

perubahan karena diduga $\mathrm{pH}$ snack nori

sedikit mengalami perubahan (Marcella, 2011).

\section{Aktivitas Antioksidan}

Antioksidan adalah senyawa pemberi elektron atau reduktan. Senyawa ini mampu menginaktivasi berkembangnya

radikal bebas melalui reaksi oksidasi.

Antioksidan bekerja dengan cara

mendonorkan satu elektronnya kepada senyawa yang bersifat oksigen sehingga aktivitas senyawa oksidan tersebut dapat dihambat (Winarsi, 2010). Hasil analisa aktivitas antioksidan dapat dilihat pada Gambar 5.

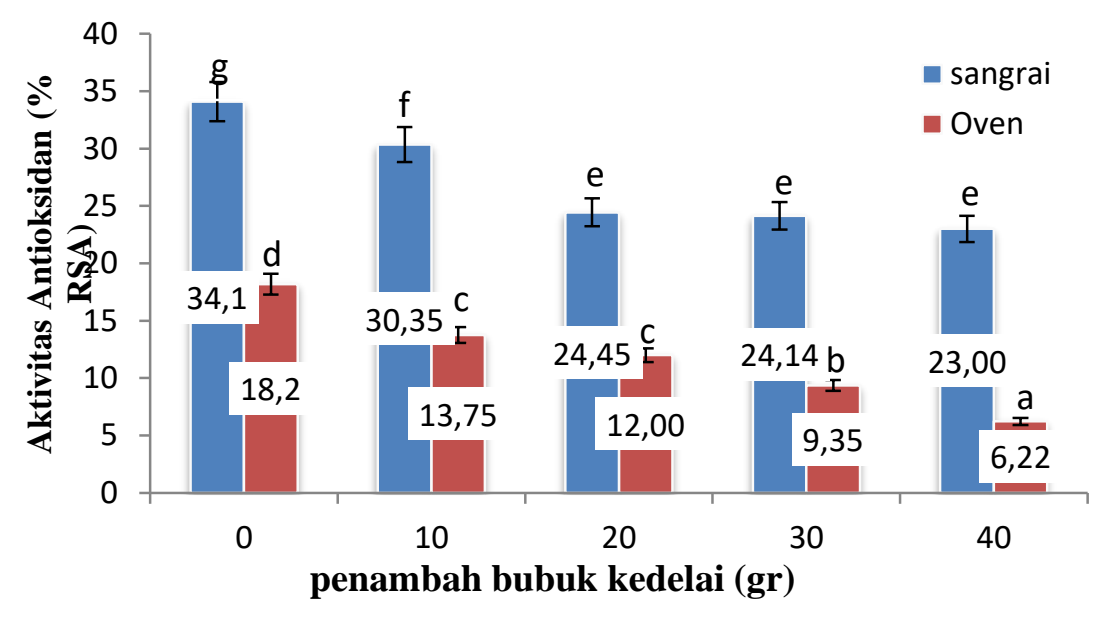

Gambar 5. Aktivitas antioksidan serbuk serbuk beras hitam

Keterangan: superkrip yang berbeda menunjukan hasil yang berbeda nyata $(\mathrm{p}<0,05)$, nilai terendah dimulai dari superskrip a, b, d, e, f kemudian $g$

Uji statistik pada taraf signifikansi 5\% menunjukkan bahwa metode pemasakan dan penambahan bubuk kedelai serta interaksi antara keduanya ada pengaruh terhadap aktivitas antioksidan hal ini ditunjukan dengan nilai $\mathrm{p}$ metode pemasakan $0,000 \quad(\mathrm{p}<0,05)$, nilai $\mathrm{p}$ penambahan bubuk kedelai 0,000 $(\mathrm{p}<0,05)$ dan interaksi metode pemasakan dan prosentase penambahan bubuk kedelai sebesar dengan p 0,016 ( $\mathrm{p}<0,05)$. Hasil uji lanjut duncan menunjukan adanya perbedaan nyata. Semua sampel yang diujikan ada perbedaan signifikan kecuali 
pada penambahan bubuk kedelai 20, 30 dan 40 gr metode sangrai.

\section{Cita Rasa}

Cita rasa merupakan atribut makanan yang meliputi penampakan, bau, rasa, tekstur, dan suhu. Cita rasa merupakan bentuk kerja sama dari kelima macam indera manusia, yakni perasa, penciuman, perabaan, penglihatan, dan pendengaran. Rasa sendiri merupakan hasil kerja pengecap rasa (taste buds) yang terletak di lidah, pipi, kerongkongan, atap mulut, yang merupakan bagian dari cita rasa. Tingkat penilian panelias terhadap cita rasa serbuk beras hitam dapat dilihat pada Gambar 3.

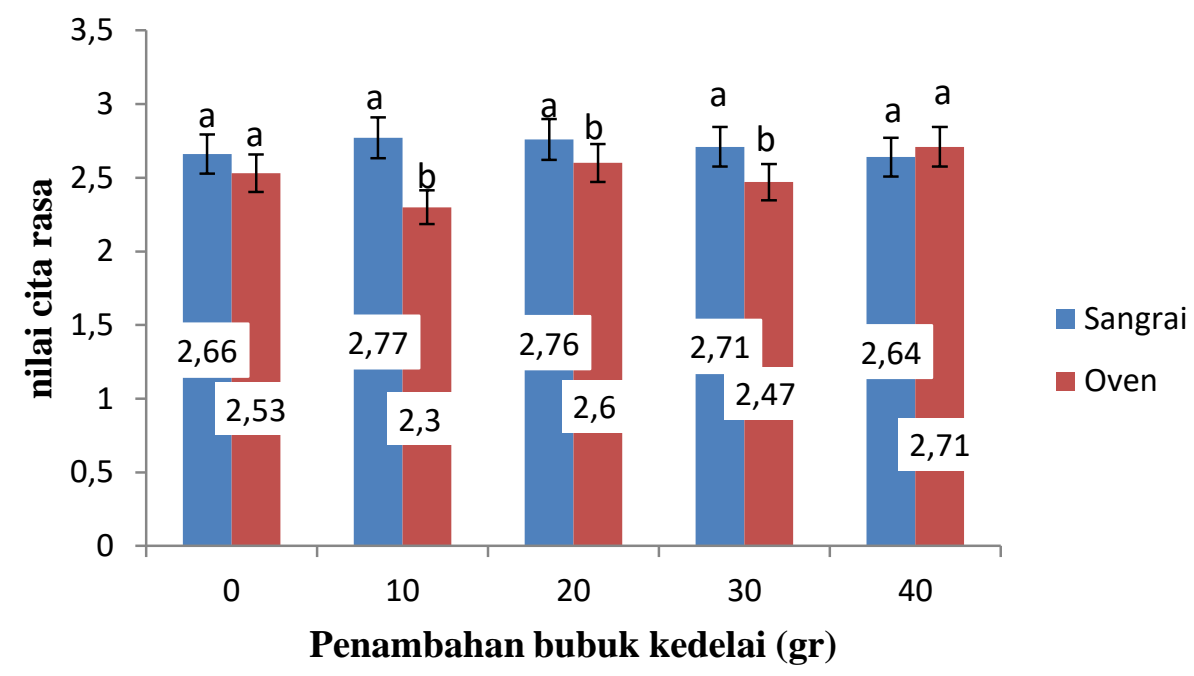

Gambar 3. Rerata nilai cita rasa serbuk beras hitam

Keterangan: superkrip yang berbeda menunjukan hasil yang berbeda nyata $(\mathrm{p}<0,05)$

Uji statistik Friedman didadaptkan $\mathrm{p}$ value $0.000(\mathrm{p}<0,05)$ pada taraf $5 \%$ menunjukan adanya perbedaan pengaruh metode pemasakan dan penambahan bubuk kedelai pada serbuk beras hitam terhadap nilai uji cita rasa, hasil uji lanjut wilcoxon menunjukan adanya perbedaan pada masing-masing perlakuan terhadap nilai cita rasa warna serbuk beras hitam. Pada perlakuan kontrol sangrai dan oven tidak 
ada perbedaan cita rasa yang signifikan.

Berdasarkan gambar 9 nilai cita rasa dipengaruhi oleh metode pemasakan sangrai oven kecuali pada perlakuan sangrai dan oven penambahan kedelai 40 gr tidak ada perbedaan yang nyata.

Adanya perbedaan cita rasa pada serbuk beras hitam dipengaruhi oleh metode pemasakan sangrai dan oven. Hal tersebut juga sama pada nilai aroma dan rasa yang menunjukan perbedaan pada perlakuan metode pemasakan. Menurut Valentin et al., (2006) Penambahan bubuk kedelai berpengaruh pada cita rasa karena protein merupakan senyawa pemberi rasa umami, senyawa pemberi sensasi ini akan berperan melalui protein $\mathrm{G}$ yang mengkait pada reseptor dan mengaktifkan pembawa pesan kedua (second messenger). Senyawa pemberi umami yang paling dikenal dan potensial adalah L-glutamat, asam amino yang terdapat dalam protein hampir semua produk pangan terutama daging, ikan dan kacang-kacangan. Asam glutamat bebas secara alami terdapat dalam sumber pangan nabati diantaranya pada kedelai kuning dan hitam. Pada proses metode penyangraian mengakibatkan hilangnya senyawa akibat terdegradasi. Karbohidrat terdegradasi membentuk sukrosa dan gulagula sederhana yang menghasilkan rasa manis sehingga metode pemasakan sangrai menghasilkan nilai citarasa yang lebih tinggi dibandingkan dengan metode pemasakan oven (Sari, 2001).

\section{Penentuan Perlakuan Terbaik Berdasarkan Kadar Antosianin,} Aktivitas Antioksidan dan Sifat Sensori

Perlakuan terbaik dari semua perlakuan yang diteliti diperoleh melaluhi penentuan nilai rata-rata dari variabel yang digunakan, meliputi: kadar antosianin, aktivitas antioksidan dan mutu hedonik. Data perlakuan terbaik disajikan pada tabel 1. 
Tabel 1. Analisa kimia dan sensoris serbuk beras hitam

\begin{tabular}{llll}
\hline Sampel & $\begin{array}{l}\text { Kadar antosianin } \\
(\mathrm{ppm})\end{array}$ & $\begin{array}{l}\text { Aktivitas } \\
\text { antioksidan (\% RSA) }\end{array}$ & $\begin{array}{l}\text { Nilai uji } \\
\text { sensoris }\end{array}$ \\
\hline Sangrai 0\% & $5,38 \mathrm{c}$ & $32,86 \mathrm{~g}$ & 2,66 \\
Sangrai 10\% & $\mathbf{4 , 6 7 c}$ & $\mathbf{2 9 , 8 0 f}$ & $\mathbf{2 , 7 7}$ \\
Sangrai 20\% & $3,28 \mathrm{~b}$ & $24,53 \mathrm{e}$ & 2,76 \\
Sangrai 30\% & $3,28 \mathrm{a}$ & $23,65 \mathrm{e}$ & 2,71 \\
Sangrai 40\% & $3,11 \mathrm{a}$ & $23,65 \mathrm{e}$ & 2,64 \\
Oven 0\% & $7,14 \mathrm{~d}$ & $17,94 \mathrm{~d}$ & 2,53 \\
Oven 10\% & $5,50 \mathrm{c}$ & $15,27 \mathrm{c}$ & 2,30 \\
Oven 20\% & $3,44 \mathrm{~b}$ & $11,29 \mathrm{c}$ & 2,60 \\
Oven 30\% & $3,28 \mathrm{a}$ & $9,23 \mathrm{~b}$ & 2,47 \\
Oven 40\% & $\mathbf{3 , 1 1 a}$ & $\mathbf{8 , 0 8 a}$ & $\mathbf{2 , 7 1}$ \\
\hline
\end{tabular}

Keterangan: (1) perlakuan terbaik ditandai dengan kata yang dicetak tebal

(2) superkrip yang berbeda menunjukan hasil yang berbeda nyata $(\mathrm{p}<0,05)$, nilai terendah dimulai dari superskrip a, b, d, e, f kemudian g

Berdasarkan tabel 1 serbuk beras hitam dengan metode pemasakan sangarai perlakuan terbaik pada konsentrasi penambahan bubuk kedelai $10 \%$ dan pada metode pemasakan oven perlakuan terbaik terdapat pada penambahan bubuk kedelai 40\%. Serbuk beras hitam di pengaruhi oleh metode pemasakan konsentrasi penambahan beras hitam. Perlakuan terbaik diambil pada masing-masing metode pemasakan untuk metode sangrai penambahan bubuk kedelai $10 \%$ merupakan perlakuan terbaik hal ini karena nilai uji sensoris tertinggi dan nilai antioksidan yang tidak terpaut jauh dengan kontrol. Pada metode pemasakan oven perlakuan terbaik diambil pada pemberian konsentrasi $40 \%$ hal ini berdasarkan pada uji sensoris paling tinggi dengan nilai 2,71 dan nilai aktivitas antioksidan dan antosianin.

Nilai Kadar air, Kelarutan dan Protein

\section{Perlakuan Terbaik}

Nilai kadar, kelarutan dan protein pada serbuk beras hitam di analisis pada perlakuan terbaik dengan pembanding kontrol pada masing-masing perlakuan (sangrai $0 \%$ dan oven $0 \%$ ) dengan perlakuan terbaik masing-masing perlakuan yang sudah dibahas pada bab sebelumnya yaitu pada sangrai $10 \%$ dan 
Oven 40\%. Berikut nilai kadar air,

Tabel 7.

kelarutan dan protein dapat dilihat pada

Tabel 7. Nilai kadar air serbuk beras hitam pada perlakuan terbaik

\begin{tabular}{|c|c|c|c|}
\hline Sampel & Kadar air (\%) & Kelarutan (\%) & Protein (\%) \\
\hline $\begin{array}{l}\text { Kontrol sangrai tanpa } \\
\text { dekstrin }\end{array}$ & - & 79,90 & - \\
\hline Kontrol sangrai & 4,83 & 85,27 & 10,46 \\
\hline Kontrol oven & 4,96 & 84,71 & 10,83 \\
\hline Sangrai $10 \%$ & 4,85 & 84,22 & 14,68 \\
\hline Oven $40 \%$ & 5,01 & 83,23 & 19,42 \\
\hline
\end{tabular}

Keberadaan air dalam bahan pangan dapat menjadi indikator daya awet bahan tersebut karena aktivitas mikroba sangat tergantung pada aktivitas air bahan tersebut sehingga semakin kecil kadar air dalam bahan pangan semakin besar daya awetnya (Tejasari, 2005).

Kadar air serbuk beras hitam berkisar antara 4,83 sampai 5,01 \% kadar air tersebut sudah sesuai dengan syarat mutu serbuk BSN-SNI No.4320-1996 kadar air dalam serbuk berkisar antara 3\% sampai 5\%. Kadar air terendah terdapat pada perlakuan kontrol sangrai dan tertinggi pada perlakuan oven $40 \%$. Kadar air dalam serbuk beras hitam dipengaruhi oleh metode pemasakan yang berbeda (sangrai dan oven).

Kelarutan atau Solubility adalah kuantitas maksimal suatu zat terlarut (solut) untuk dapat larut pada pelarut tertentu membentuk larutan homogen (Paramita, 2014). Kelarutan serbuk beras hitam berkisar antara 83,23\% - 85,27\%. Nilai kelarutan paling tinggi terdapat pada perlakuan sangrai kontrol dan paling rendah pada perlakuan oven $40 \%$. Menurut Khotimah (2006) kelarutan 
berhubungan dengan kadar air bahan, dimana semakin tinggi kadar air kelarutan cenderung semakin kecil, karena jika kadar air tinggi terbentuk gumpalan-gumpalan sehingga dibutuhkan waktu yang lama untuk memecah ikatan antar partikel dan kemampuan produk untuk larut menurun sebagai akibat total padatan yang tersaing pada pelarut. Kadar protein paling tinggi terdapat pada sampel oven $40 \%$ sebesar $19,428 \%$ dan yang paling rendah pada perlakuan kontrol sangrai sebesar 10,461\% Hal ini dikarenakan kandungan protein pada bubuk kedelai berkisar antara 23,45 $\%$ sampai 23,83\% (BPTP, 2011) lebih besar dari pada kandungan protein pada beras hitam sebesar 7,18\% (Nurhidajah, 2017).

\section{KESIMPULAN}

Metode pemasakan dan penambahan bubuk kedelai dan interaksi keduanya berpengaruh terhadap kadar antosianin pada serbuk beras hitam, uji lanjut menunjukan ada perbedaan antara penambahan bubuk kedelai $10 \mathrm{gr}$ sampai 40gr, tidak ada perbedaan antara metode oven dan sangrai kecuali pada perlakuan kontrol. Metode pemasakan dan penambahan bubuk kedelai dan interaksi keduanya berpengaruh terhadap aktivitas antioksidan pada serbuk beras hitam, uji lanjut menunjukan ada perbedaan antara penambahan bubuk kedelai dan metode pemasakan pada semua sampel kecuali pada metode sangrai penambahan bubuk kedelai 20-40\%. Metode pemasakan dan penambahan bubuk kedelai dan interaksi keduanya berpengaruh terhadap sifat organoleptik (warna, aroma, rasa kecuali kekentalan) pada serbuk beras hitam nilai sensoris tertinggi terletak pada bubuk kedelai 10 gr dengan metode pemasakan sangrai dengan nilai cita rasa 2,77 (mendekati suka). Perlakuan terbaik serbuk beras hitam berdasarkan uji organoleptik, kadar antosianin dan aktivitas antioksidan terdapat pada penambahan bubuk kedelai 10 gr pada metode pemasakan sangrai. Persyaratan mutu kadar air serbuk beras 
hitam sudah sesuai BSN-SNI No.4320-

1996 yaitu berkisar antara 3\% sampai 5\%.

\section{DAFTAR PUSTAKA}

AOAC (Association of Official Agricultural Chemist). 2005. Official Methods of Analysis. 18th ed. AOAC International. USA.

Avila, M., Hidalgo, M., Moreno, C.S., Pelaez, C., Requena, T.,dan dePascuel Teresa, S., 2009, Bioconversion of anthocyanin glycosides by Bifidobacteria and Lactobacillus, Food Research Int 42: 1453-1461

Brilia, M. Nelly, P. Shirley, E. 2015. Gambaran kandungan zat- zat gizi pada beras hitam (oryza sativa l.) Varietas enekang, Fakultas Kedokteran Universitas Sam Ratulangi, Manado.

Budisanjaya, G. Wrasiati, P. Anom, M. 2015. pengaruh metode pemanasan terhadap karakteristik mutu teh beras merah jatiluwih. Fakultas Teknologi Pertanian. Universitas Udayana. Bali

Mohammed, R. Khorasani, R. G. Goonewardene, L. A. Kramer, J. K. G. Kennelly, J. J. 2011. Persistency of milk trans isomers and rumenic acid in Holstein cows over a full lactation. Can. J. Anim. Sci., 91 (1): $147-167$

Sari, L. 2001. Mempelajari Proses Pengolahan Kopi Bubuk (Coffea canephora) Alternatif dengan Menggunakan Suhu dan Tekanan
Rendah. Skripsi S1. Tidak Dipublikasikan. Fakultas Teknologi Pertanian Institut Pertanian Bogor, Bogor.

Stevi, A. 2015. pembuatan formula serbuk (fungsional) berbasis beras hitam (oryza sativa $l$. indica) dengan variasi lama perendaman beras hitam untuk orang lanjut usia. Fakultas Teknologi Pertanian. Universitas Gajah Mada. Yogyakarta.

Suardi, D. dan I. Ridwan. 2009. Beras hitam, pangan berkhasiat yang belum populer. Warta Penelitian dan Pengembangan Pertanian 31(2): 9-10.

Sumiati T. 2008. Pengaruh pengolahan terhadap mutu cerna protein ikan mujair (Tilapia mossambica). Program Studi Gizi Masyarakat dan Sumberdaya Keluarga, Fakultas Pertanian. Institut Pertanian Bogor, Bogor

Sompong, R. Siebenhandl, S. Linsberger, M. Berghofer, E. 2011. Physicochemical and antioxidative properties of red and black rice varieties from Thailand, China and Sri Lanka. J. Food Chem. 124 (2011) 132-140.

Syarifa, R.N., dan E. Teti. 2013. Pemanfaatan Talas Berdaging Umbi Kuning (Colocasia esculenta (L) Schott) dalam Pembuatan Cookies. Jurnal Pangan dan Agroindustri. 1:1 hal 46-55.

Tejasari. 2005. Nilai-nilai Gizi Pangan. Yogyakarta: Graha Ilmu. 
Valentin. 2006. Taste-odour interactions in sweet taste perception. In W. J. Spillane (ed). Optimising Sweet Taste in Foods. Woodhead Publishing Limited. Cambridge, England

Winarsih.2010. Protein Kedelai dan Kecambah Manfaatnya Bagi
Kesehatan. Yayasan Kanisius,

Yogyakarta

Winarno FG. 2004. Kimia pangan dan gizi. PT. Gramedia Pustaka Utama, Jakarta 